\title{
ロボットマニピュレータの制御モード切り替え法に関する研究*
}

(第 1 報, 位置と力の偏差に基づく制御モード切り替え法の提案)

\author{
山崎 容次郎*1, 横川隆一*2 \\ 積 際徹*2, 原敬*3
}

\section{A Study on a Method for Switching Control Mode of Robot Manipulators (1st Report, A proposal of a Method for Switching Control Mode Based on Position and Force Errors)}

Yojiro YAMASAKI*4, Ryuichi YOKOGAWA, Toru TSUMUGIWA and Kei HARA

${ }^{* 4}$ Department of Mechanical Engineering, Takamatsu National College of Technology,

355 Chokushi-cho, Takamatsu-shi, Kagawa, 761-8058 Japan

\begin{abstract}
This paper proposes a new switching method of control mode for a robot manipulator coming in contact with environment that has elasticity. First, the basic concept of the switching of the control mode in a robot manipulator is explained. Second, we propose a new method of switching the control mode that selects the control mode at the intersection of "Characteristic curve of position and force" and "Target value of the work composed by the desired value of position and force". Next, the switching algorithm based on this method is obtained about a certain work coordinate with a Multi-DOF robot manipulator. In this paper, the switching method is named "A Method for Switching Control Mode Based on Position and Force Errors". Furthermore, when a One-DOF robot manipulator driven by DC servo motor with reduction gears using an elastic joint came in contact with the object that has elasticity, the simulation and the experiment on various angle and torque controls were done. As a result, it is shown that the proposed switching method is useful and has stable and flexible characteristics.
\end{abstract}

Key Words : Robot, Manipulator, Motion Control, Force Control, Position Control, Elastic Joint, Control Mode, Method for Switching Control Mode

\section{1. 緒言}

ロボットマニピュレータ(以下ロボットと呼ぶ)の 一般的な制御法には位置制御と力制御(1)があり，こ れらの制御法を自在に使うことができれば人の手のよ うにロボットに複雑な作業をさせることができる. 他 方, 力制御系には位置制御ベース力制御系と呼ばれる 内部ループに位置 (あるいは速度) 制御系を有しその 外側に力制御系を付加した力制御系と, トルク制御 ベースカ制御系と呼ばれる直接関節トルクを指令值と する力制御系の二つ(2)がある.これらより, 位置制 御と力制御を組み合わせる方式には, 位置制御ベース 力制御系を用いる方式と, 位置制御系とトルク制御 ベースカ制御系を用いて制御モードを切り替える二つ

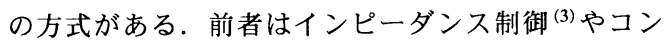
プライアンス制御 ${ }^{(4)}$ が代表的で, 位置制御ベースの

* 原稿受付 2007 年 9 月 12 日.

*1 正員, 高松工業高等専門学校(画761-8058 高松市勅使町 355).

*2 正員, 同志社大学工学部(亚610-0394 京田辺市多々羅都谷 1-3).

*3 正員, 永年会員, 同志社大学工学部.

E-mail : yamasaki@takamatsu-nct.ac.jp
ため位置制御に関する信頼性は高い。しかし，力を制 御するためには環境との距離や環境の形状を正確に把 握しておくことが必要であり環境の変化に対して適応 性がそしい。一方, 制御モードを切り替える方式は, トルク制御ベース力制御系を用いるため直接力を制御 でき環境の変化に対して適応性は高い. ところが，切 り替え方法について詳しく検討された研究は少ない.

制御モ一ドの従来の切り替え方法では，ある闎値 以上の反作用力があれば位置制御から力制御に切り替 える手法 ${ }^{(5-7)}$ が用いられている. ハイブリッド制御 ${ }^{(8)}$, モ一ド切り替え型位置/力制御 ${ }^{(9)}$, 位置制御から力 制御に移る移行過程での衝突力の低減を目的とした制 御モードの決定方法 ${ }^{(10)}$, 学習に基づいて接触位置を 同定し接触前から力制御に切り替える方法 ${ }^{(11)}$ でも基 本的には同様の切り替え法を利用している.

しかし，これらの切り替え法は反作用力が闇值以 上になっているかどうかで制御モ一ドが単純に決定さ れるため, 位置制御と力制御の複雑な切り替えを要す る作業には対応できない。例えば，一旦，力制御モ一 
ドになれば，その後自律的に位置制御モードに戻るこ とはなく，また，設定した閾值以上に反作用力を受け る場合は位置制御ができないことなどが挙げられる。

そこで，人の指の制御についてあらためて考えると 位置制御と力制御を選択的に行っていることに気づく. 例えば図 1 のように, 硬くて重い鋼球(図 $1(\mathrm{a})$ ) と柔 らかくて軽いゴムボール(図 1 (b)) 2 本指で把持す る場合を考える．前者では，指で物体に力を加えても 物体が硬いため変形せず落下に打ち勝つ摩擦力を得る ため力制御で把持する. 後者では, 指の位置制御によ り物体を変形させ把持に必要な摩擦力を得る。すなわ ち，力を加えながら指の位置制御で把持する．このよ うに反作用力が間值以上になっているかどうかだけで 制御モ一ドを切り替えるのではなく，適した制御モ一 ドを判断し，位置制御と力制御を自律的に切り替える ことのできる制御系を構築する必要がある.

そこで本稿では，最初にロボットの制御モード切 り替えの基本概念を説明する。ここで，多関節ロボッ トの運動制御は各作業座標軸あるいは各関節の運動制 御に分解されるので，各座標軸単位あるいは関節単位 で位置と力の制御モードを切り替えることを考えれば よい. したがって，作業座標軸についての位置と力の 制御モ一ド切り替え法について述べる.

次に，弾性を有する環境 (未知対象物)への接触を 想定し，負荷に感応し適した制御モードに自律的に切 り替える新しい制御モード切り替え法を提案する。な お，本稿ではこの制御モ一ド切り替え法を位置と力の 偏差に基づく制御モード切り替え法 ${ }^{(12)}$ (SCOME 法 :

A Method for Switching Control Mode Based on Position and Force Errors) と呼ぶ.

さらに，弾性関節を有する減速機付 DC サ一ボモ一 夕駆動の 1 自由度ロボットについて, 位置 (回転角) と力(トルク)の制御シミュレーションと実機を用い た制御実験を行ない, 提案する制御モ一ド切り替え法 の有効性を確認，検証する.

\section{2. 制御モード切り替えの基本概念}

$2 \cdot 1$ ロボットと環境のモデリング $n$ 自由度の 剛体リンクからなる多関節ロボットのモデルを図 2 に

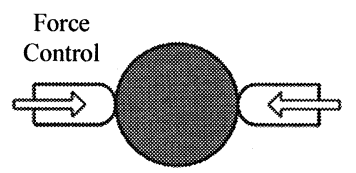

(a) Hard Object

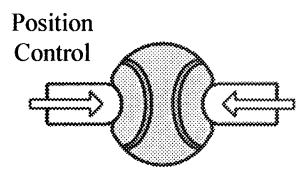

(b) Soft Object
Fig.1 Contacts with object
示す、ロボットの灰色部分は基準姿勢を，黒色は変位 後を表す。また，ロボットの基準座標系を $\boldsymbol{\Sigma}_{0}$ ，手先 の作業座標系を $\boldsymbol{\Sigma}_{\mathrm{H}}$ とする，図 2 より，拘束空間での ダイナミクスを式 (1)に，ロボットが対象物に作用す る接触力 $\boldsymbol{F}$ (ロボットが対象物から受ける反作用力 $\left.\boldsymbol{F}_{e}=-\boldsymbol{F}\right)$ を式(2)に示す. なお, 自由空間でのダイナ ミクスは式(1)で $\boldsymbol{F}=0$ としたものに他ならない

$$
\begin{aligned}
& \tau=\boldsymbol{M}(\boldsymbol{\theta}) \ddot{\boldsymbol{\theta}}+\boldsymbol{h}(\boldsymbol{\theta}, \dot{\theta})+J^{T} F \\
& F=K_{e} x+D_{e} \dot{\boldsymbol{x}}
\end{aligned}
$$

ここで, $\tau \in R^{n \times 1}$ は関節トルク， $M(\theta) \in R^{n \times n}$ は慣 性行列, $\theta \in R^{n \times 1}$ は関節角, $h(\theta, \dot{\theta}) \in R^{n \times 1}$ はコリオ リ力, 求心力, 重力, 粘性摩擦力等からなる非線形項, $J \in R^{n \times n}$ はヤコビ行列である.また, $F \in R^{n \times 1}$ は接 触力, $K_{e} \in R^{n \times n}$ と $D_{e} \in R^{n \times n}$ は環境剛性行列と環境 粘性行列, $x \in R^{n \times 1}$ は作業座標系での位置/姿勢を 表す. さらに, 順運動学 $D K$ と逆運動学 $I K$ とすると, 式 (1)，(2) は式 (3)，(4)に変形できる。ただし，Jは 正則 $(\operatorname{rank} J=n, n \leqq 6)$ と仮定した.

$$
\begin{aligned}
\tau & =M(I K(x)) J^{-1} \ddot{x}-M(I K(x)) J^{-1} j^{-1} \dot{x} \\
& +h\left(I K(x), J^{-1} \dot{x}\right)+J^{T} F \\
F & =K_{e} D K(\theta)+D_{e} J \dot{\theta}
\end{aligned}
$$

式 (1)と式 (4) は関節座標系での運動を, 式 (2) と式 （3）は作業座標系での運動を表している．どちらの座 標系においても，適当なモ一夕駆動トルクぇを与えれ ば，自由空間では位置制御することができ，拘束空間 では力制御できることを示している，言い換えれば, 関節座標系においては関節単位で，作業座標系では作 業座標軸単位で, 位置制御と力制御の制御モードの切 り替えが可能であることを示唆している.

$2 \cdot 2$ 位置とカの特性曲楾 今, 作業座標系で位 置と力の制御が安定に実現できる多自由度ロボットを 想定し，アームの先端をある作業座標軸 $\mathbf{X}_{\mathbf{i}}$ 方向に動

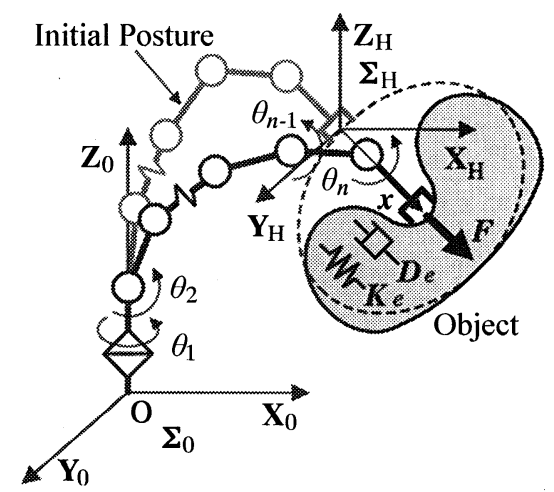

Fig.2 Robot manipulator model 
作開始点 (原点 0 ) から直線的に変位させ，未知の対象

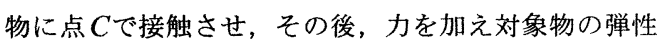
曲線に添って接触力を変化させることを考える．この とき, 手先位置 $x$ と対象物に作用する $\mathbf{X}_{\mathbf{i}}$ 方向の接触 力 $F$ を図 3 に $x-F$ 線図として示す，なお，本稿では 位置と力の制御を同一軌道上で考え, 位置変位曲線 $\left(\right.$ 点 $0 \rightarrow$ 点 $C$ ) と力の弾性曲線 (点 $C \rightarrow$ 点 $E_{1}, E_{2}, E_{3}$ )を あわせて位置と力の特性曲線 (Characteristic Curve ofPosition and Force) と呼ぶ.ここで, 対象物の弾性曲線 は, 作業座標軸 $\mathbf{X}_{\mathbf{i}}$ 方向での対象物の変形量を $x^{\prime}$, 剛 性を $K_{e}$ ，粘性係数を $D_{e}$ とすると，一般に式(5)の 3 種類に分けられる．式(5)を考慮し，図 3 には，完全 剛体 $C E_{1}$, 弾性体 $C E_{2}$, および, ゴムなどの柔らか な粘弾性体 ${ }^{(7)} C E_{3}$ の弾性曲線を示した.

$$
\left.\begin{array}{ll}
C E_{1} \text { : 完全風体 } & F=K_{e} x^{\prime}, K_{e}=\infty \\
C E_{2} \text { : 弾性体 } & F=K_{e} x^{\prime} \\
C E_{3}: \text { 粘弾性体 } & F=K_{e} x^{\prime}+D_{e} \dot{x}^{\prime}
\end{array}\right\}
$$

この位置と力の特性曲線を考慮すれば，ロボット の運動を位置制御から力制御(あるいはその逆)の連 続的な運動と捉えることができる.

\section{3 位置制御と力制御の切り替えのある制御系}

入力を位置と力, 出力は位置と力のいずれかとす る制御系を図 4 に示す. 図 4 より, 任意の位置制御器 と力制御器をラプラス領域で $G_{x}(s), G_{F}(s)$ と仮定す ると, 時刻 $t=t_{0}$ における各制御器から得られる操作 信号 $\Delta x, \Delta F$ は式 (6)，（7）で表される.ここで, $x^{d}, F^{d}$ は位置の目標値と力の目標值, $x^{r}, F^{r}$ は位置

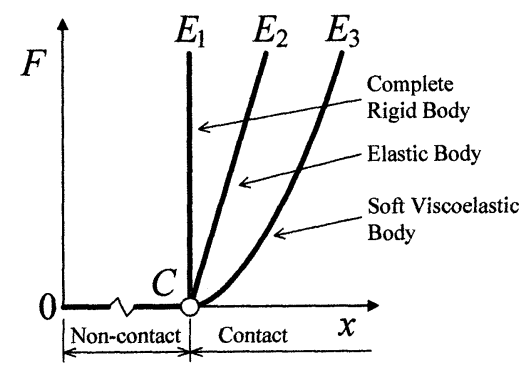

Fig. 3 Characteristic curves of position and force

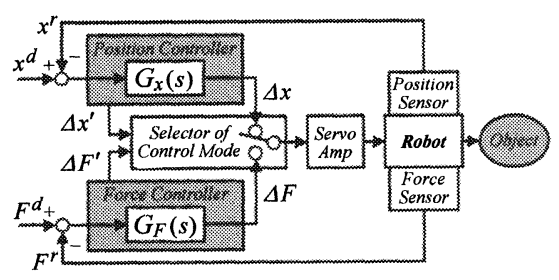

Fig.4 A control system with a method for switching control modes
の応答值と力の応答値 (位置センサの出力値とカセン サの出力值を表し， $t=t_{0}$ では定数值とみなす)とし, $\mathscr{L}^{-1}$ はラプラス逆変換を表す.

$$
\begin{aligned}
& \Delta x=\mathscr{L}^{-1}\left\{G_{x}(s)\right\}_{t=t_{0}}\left(x^{d}-x^{r}\right) \\
& \Delta F=\mathscr{L}^{-1}\left\{G_{F}(s)\right\}_{t=t_{0}}\left(F^{d}-F^{r}\right)
\end{aligned}
$$

位置制御と力制御の切り替えはサーボアンプに入力 される操作信号 $\Delta x, \Delta F$ を切り替えることを意味し， 各制御器から得られるモード信号 $\Delta x^{\prime}, \Delta F^{\prime}$ を制御 モード選択器で比較することで, 切り替えの判断選択 を行えばよい。ここで問題となるのが, 操作信号 $\Delta x, \Delta F$ とモード信号 $\Delta x^{\prime}, \Delta F^{\prime}$ の次元 (または単位), および $\Delta x^{\prime}, \Delta F^{\prime}$ を用いた切り替えアルゴリズムであ る. 安定な切り替えのためには両操作信号 $\Delta x, \Delta F$ の 次元が同じで, かつ, 制御モードの切り替え時に操作 信号 $\Delta x, \Delta F$ が連続することが望ましい. また，モー ド信号 $\Delta x^{\prime}, \Delta F^{\prime}$ の次元も同じでなければならない.

そこで，1 章に示した位置制御ベースカ制御系と卜 ルク制御ベース力制御系の二つの力制御系 ${ }^{(2)}$ の構造 を考慮し, 制御モード切り替え時の操作信号の次元が 同じとなるように選択器の挿入位置に配慮した 2 入力 1 出力制御系をあらためて図 5 に示す. 図 5 (a) は力制 御に位置制御ベース力制御系を, 図 5(b) は力制御に トルク制御ベース力制御系を用いた場合である.ここ で, 図中の Velocity Servo Amp は速度制御型アンプ を, Torque Servo Amp はトルク制御型アンプを表わ している. 図 5(a)より, 位置制御ベース力制御系に も制御モード切り替え機能を付加できることがわかる. なお, 図 5(a), (b)の両図ともに, 選択器に入力さ れる信号のうち一方は目標値となっている.このよう に, 選択器に入力される $\Delta x, \Delta F$ が目標值であっても， 本稿では便宜的に $\Delta x, \Delta F$ を「操作信号」，あるいは 「信号」と呼ぶことに注意されたい.

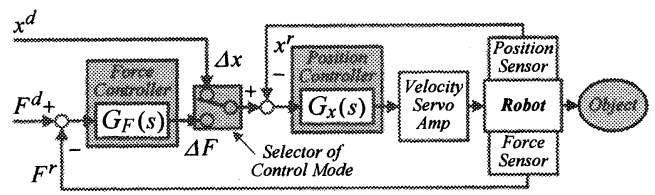

(a) Force contorol system based on position control

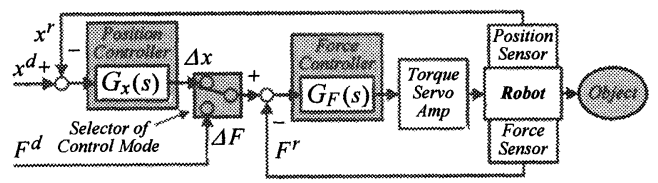

(b) Force contorol system based on torque control

Fig.5 Control systems with a method for switching control modes 
また, 図 $5(\mathrm{a})$ の操作信号 $\Delta F$ の次元は, 式(7)により 偏差 $\left(F^{d}-F^{r}\right)$ の次元 $[\mathrm{N}]$ から $[\mathrm{m}]$ に次元変換され, 同 様に, 図 $5(\mathrm{~b})$ の操作信号 $\Delta x$ の次元は, 式 (6)により $[\mathrm{m}]$ から $[\mathrm{N}]$ に次元変換されている. したがって, 選択 器に入力される信号 $\Delta x$ と $\Delta F$ の次元は図 $5(\mathrm{a})$ では位 置[m], 図 5(b)では力[N]となる.これらより, 図 5(a), （b）ともにそれぞれの選択器に入力される信号の次元 は同じになり制御モードの切り替えは可能となる.

さらに, 位置制御系と力制御系の両方が安定であり, かつ, 制御モードの切り替え時に操作信号が連続して いれば，制御モードを切り替えた後も制御系全体は安 定と判断できる.したがって，制御モードの切り替え 時に操作信号が「連続する」かどうかが重要な問題と なる．操作信号が連続するためには任意の時刻で各制 御器から得られる操作信号が過去の履歴とは無関係に 一意に決まる必要がある。すなわち，図 5(a)，（b)の 外部ループの制御器に積分要素がないことが必要条件 となる。この条件を満たさない制御系には，図 5(a) では力制御器にインピーダンス制御やコンプライアン ス制御を用いた場合, 図 5(b)では位置制御器に IP 制 御やPI制御を用いた場合が該当する.

以上より, 制御モ一ドの切り替え時に操作信号が連 続しないタイプの制御系を除けば, 図 5(a) と図 5(b) の制御系の制御モードの切り替えは可能である. また, 図 5(a), (b) の両図ともに, 次の 3 章に示す同じ制御 モード切り替え法が適用できる.

\section{3. 位置とカの偏差に基づく制御モード切り替え法}

\section{1 位置とカの偏差に基づく制御モード切り替え}

法の提案 具体的な制御モード切り替え法として, 著者の一人がその開発当初から関わってきた油圧ポン プの流量制御と圧力制御に関する制御モード切り替え 法 ${ }^{(13,14)}$ を本稿のロボット制御に応用する. 油圧ポン プの制御に用いた制御モード切り替え法では制御モ一 ドの切り替えの判断に用いるモード信号は実操作信号 でなくてもよいとされたが, 制御モードの切り替え時
に操作信号が連続することが望ましい，そこで，時刻 $t=t_{0}$ のモード信号に式 (6)，（7）の実際の操作信号 $\Delta x, \Delta F$ を用いる. そして, 時刻 $t=t_{0}$ において位置

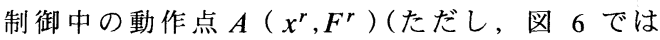
$\left.F^{r}=0\right)$ に対して目標点 $D\left(x^{d}, F^{d}\right)$ を与えた場合の 柔らかな粘弾性体 ${ }^{(7)}$ に対する $x-F$ 線図を図 6 に示し, 制御モードの切り替え方法を検討する.なお, 目標点 の与え方を変え, ロボットの動作を次の 3 つの場合に 分けて考える. 図 6(a) はロボットが対象物に非接触 のまま位置変化するように目標点 $D$ を与えた場合,

図 6(b1)，（b2）はロボットが対象物に接触するように 目標点 $D$ を与え, また, 目標点 $D$ が位置と力の特性 曲線の上側と下側になる場合である.

今ある状態 $A\left(x^{r}, F^{r}\right)$ で制御されたロボットに, 位置と力の両方の目標值を含む目標点 $D\left(x^{d}, F^{d}\right)$ を 与えることは，ロボットが環境に㗢きかける仕事の目 標 (目標エネルギ)を与えたことを意味する，そして， ロボットにこの仕事の目標 (目標エネルギ)に合致す るように駆動させることを考える. しかし, 実際にロ ボットが動作できるのは位置と力の特性曲線上 (図 6 の各図の太い実線部分) だけなので, 目標点 $D$ が位置 と力の特性曲線上にない限り動作点 $A$ を目標点 $D$ に 合致させることはできない，そこで，位置と力の目標 值で囲まれる境界部分 (図 6 の各図の細い実線部分) と 位置と力の特性曲線との交点の制御モードでロボット を制御することを提案する。言い換えれば，ある時刻 における制御モードの切り替え方法として, 位置と力 の偏差から計算される位置操作信号と力操作信号のう ち, 小さい方の操作信号の制御モ一ドを選択する, す なわち, 先に目標值に達した方の制御モードを選択さ せればよいことに他ならない.なお，この制御モード 切り替え法を, 本稿では位置と力の偏差に基づく制御 モード切り替え法 (SCOME 法) と呼ぶ.

図 6(a) を例にとると, 動作点 $A$ を位置目標点 $P$ ま で位置制御させるか, 力目標点 $B$ まで力制御させる かの二つの制御が考えられるが，この場合，提案する

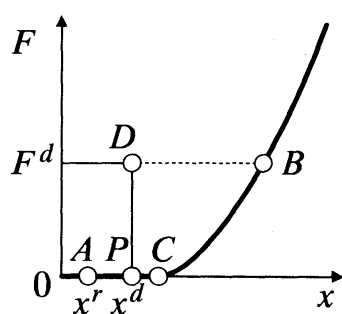

(a) Non-contact

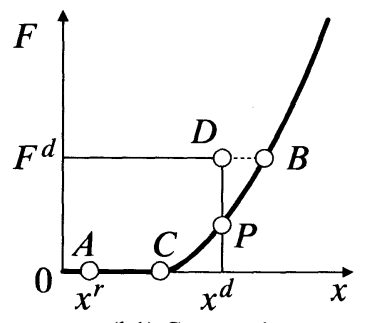

(b1) Contact 1

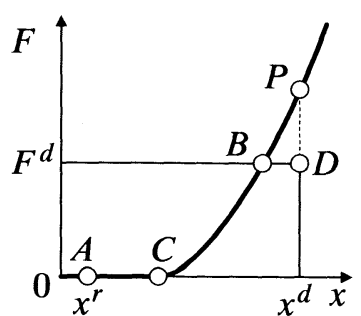

(b2) Contact 2

Fig.6 The reference points and the characteristic curve 
制御モード切り替え法を実現するため位置目標点 $P$ で位置制御させればよい. 同様に, 図 6(b1)では位置 目標点 $P$ で位置制御させ, 図 $6(\mathrm{~b} 2)$ では力目標点 $B$ で力制御をさせればよい.

3.2 切り替えアルゴリスム 時刻 $t=t_{0}$ において 動作点 $A$ が目標点 $D$ の近傍にある場合をあらためて 図 7 (a)，（b)に示す．ここで，位置と力の両操作信号 $\Delta x, \Delta F$ が等しくなる境界線を考え, 式 (6), (7) を連 立させ, 式 (8) を得る ${ }^{(14)}$.

$$
F^{r}=\frac{\mathscr{L}^{-1}\left\{G_{x}(s)\right\}_{t=t_{0}}}{\mathscr{L}^{-1}\left\{G_{F}(s)\right\}_{t=t_{0}}} x^{r}+\left[F^{d}-\frac{\mathscr{L}^{-1}\left\{G_{x}(s)\right\}_{t=t_{0}}}{\mathscr{L}^{-1}\left\{G_{F}(s)\right\}_{t=t_{0}}} x^{d}\right]
$$

式 (8) は, 時刻 $t=t_{0}$ で目標点 $D$ を通る直線を表し ておりこれを図 7 に破線で示す. $3 \cdot 1$ 節で示した提案 する制御モード切り替え法に従えば，図 7(a)では動 作点 $A$ が式 (8) より下にあるので位置制御を, 図 7 (b) では動作点 $A$ が式 (8) より上にあるので力制御を 選択すればよいことがわかる，以上を整理し，式(9) に示す切り替えアルゴリズムを得る.

$$
\left.\begin{array}{ll}
\text { Mode }=\text { Position Control } & \text { (if } \Delta x \leqq \Delta F) \\
\text { Mode }=\text { Force Control } & (\text { if } \Delta x>\Delta F)
\end{array}\right\}
$$

また，この制御モードの切り替えを実現する選択器 を図 8 に示す。図 8 の破線を選択信号 $\Delta S$ と呼ぶ.

$$
\Delta S=\Delta x-\Delta F
$$

式 (9) と式 (10) から選択信号 $\Delta S$ の符号と制御モ一 ドが連動していることがわかる.なお, 以上の議論は, 位置 $x$ を回転角 $\theta$ に, 力 $F$ をトルク $T$ に置換えれば 関節サーボ系にも同様に適用できる.

3.3 制御モード切り替え時の安定性制御モード の切り替え機能を有した制御系では, 一般的に制御 モード切り替え時の安定性が問題となる. そこで, そ の安定性について検討する，まず，本稿で提案する制 御モ一ド切り替え法は, $2 \cdot 3$ 節から位置制御系と力制御 系の両方が安定な図 5(a) または図 5(b) の制御系を用い, かつ, $3 \cdot 2$ 節から図 8 に示した制御モード選択器を有

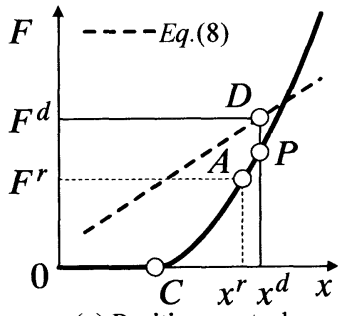

(a) Position control

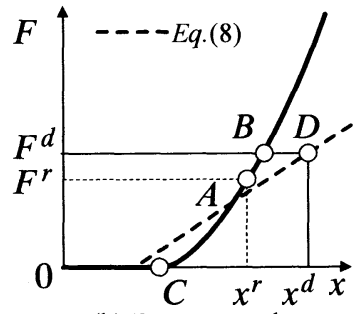

(b) Force control
Fig. $7 \mathrm{~A}$ operating point and the equation (8)
していることを前提としている．これより，本手法を 用いる場合, 制御モードの切り替え時に操作信号が連 続するので，基本的には制御モードの切り替え後も制 御系は安定であると判断できる.ただし，制御モード の切り替え後の安定性を保証するものではないことに 注意されたい.

例えば，目標点 $D$ が位置と力の特性曲線近傍にあ るとき, 制御モードが連続的に切り替わることでチャ タリングが起こることが予測される.これは，3·2 節 より, 操作信号の微小変動あるいは位置や力の応答值 に変動があれば制御モードが変動し，位置制御と力制 御が断続的に切り替わりやすくなることから理解でき る。しかし, 本手法を用いる場合, 目標点 $D$ が位置 と力の特性曲線近傍に設定されることは稀だと考えら れる. 仮に, 目標点 $D$ が位置と力の特性曲線近傍に あると推測される場合でも，所望のロボットの制御方 法が位置制御であれば図 7 (a) のように力の目標值 $F^{d}$ を大きく, 所望のロボットの制御方法が力制御であれ ば図 7 (b) のように位置の目標值 $x^{d}$ を大きくすること で, 目標点 $D$ を位置と力の特性曲線から遠ざけるこ とができ安定化が図れる.

このように，本手法を用いる場合，所望のロボット の制御方法を考虑した上で，制御モ一ド切り替え時の 安定化を図るために, 目標点 $D$ を位置と力の特性曲 線から遠ざけるように位置の目標值と力の目標值を設 定すればよい.

\section{4. 制御器の設計}

4.1 解析モデル 提案する制御モード切り替え 法の有効性を検証するため，シミュレーションと実機 実験を行う。図 5(b)の制御系が適用でき，かつ，口 ボットが対象物に接触したときの衝突力の低減化を考 虑し, 図 9 の弾性関節を有する 1 自由度ロボットを解 析モデルに選定した。 モータ, 減速機, 弾性体, ア一 ムおよび対象物で構成された図 9 の解析モデルから, 式(11) を得る(15). また, 対象物から受ける反作用力

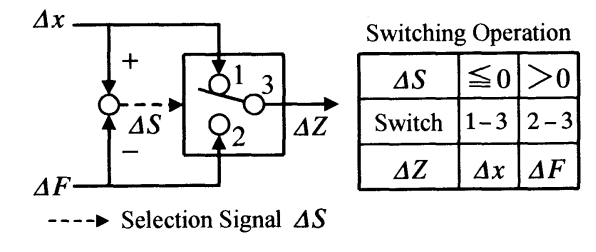

Fig.8 A selector of control modes 
$F_{e}$ ，および反作用力によるトルク $T_{e}$ は式 (12) で表さ れる.

$$
\begin{aligned}
& J_{m} \ddot{\theta}_{m}=K_{t} I_{m}-D_{m} \dot{\theta}_{m}-T_{f}-\frac{K}{N}\left(\frac{\theta_{m}}{N}-\theta_{a}\right) \\
& F_{e}=\frac{T_{e}}{L}=K_{e} L \theta_{a}^{\prime}+D_{e} L \dot{\theta}_{a}^{\prime}
\end{aligned}
$$

ここで， $J, \theta, T$ はそれぞれ慣性モーメント，回転 角とトルクを, 下付きの添元字 $m, a, e, 0$ はモー夕, アーム, 対象物, 対象物の初期位置を, $T_{f}, D$ はクー ロン摩摖と粘性摩擦, $N, K$ は減速比とトルクセンサ の剛性を表す．また， $J_{m}$ はモー夕側から見たモータ と減速機の等価慣性, $K_{t}, I_{m}$ をモータのトルク定数 之電機子電流とし, アームが対象物に接触した時の アームの回転中心から接触位置までの長さを $L$, 対 象物の変形量を $\theta_{a}^{\prime}$ とした.

$4 \cdot 2$ トルクコントローラ トルク制御系には, 金子らが導いた加速度コントローラを用いたトルク制 御法(15)を用いる. まず，モ一夕に作用する外乱 $T_{m d i s}$ を式 (13)のように定義する.ただし, 式 (13)では電 機子電流 $I_{m}$ はノミナルな参照電流值 $I_{m}^{r e f}$ に置き換え ている.ここで, 第 1 項は慣性変動トルク, 第 2 項は 粘性摩擦トルク, 第 3 項はクーロン摩擦トルク, 第 4 項はトルクリプル, 第 5 項は弾性関節によるねじれ反 力を表し, 下付きの添え字 $n$ はノミナル值を表す.

$$
\begin{aligned}
T_{m d i s} & =\left(J_{m}-J_{m n}\right) \ddot{\theta}_{m}+D_{m} \dot{\theta}_{m}+T_{f} \\
& +\left(K_{t}-K_{t n}\right) I_{m}^{r e f}+\frac{K}{N}\left(\frac{\theta_{m}}{N}-\theta_{a}\right)
\end{aligned}
$$

式 (13) の外乱 $T_{m d i s}$ を除去するため, 電機子電流 $I_{m}$ とモー夕回転角 $\theta_{m}$ は計測または計算可能とし, 図 10 に示す外乱オブザーバで推定外乱 $\hat{T}_{m d i s}$ を直接算出し, 参照電流值側に補償電流 $I_{c m p}$ としてフィードバック する. 図 10 から外乱が系に与える影響を表す式(14)

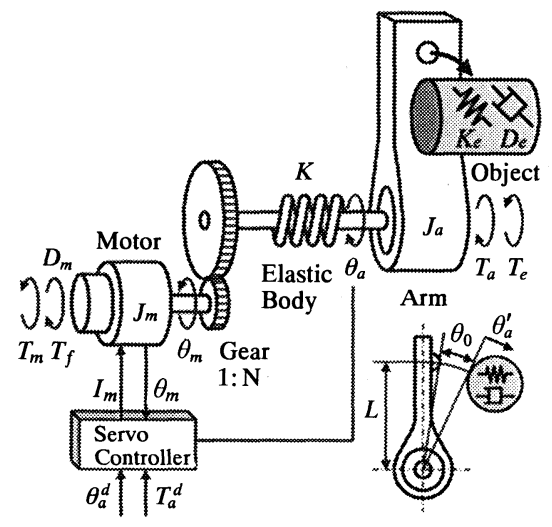

Fig.9 Simulation model
の感度関数 $G_{s}(s)$ が得られ, 外乱等価加速度 $P^{(16)}$ 用いると, 解析モデルのブロック線図は図 11 のよう に表される.

$$
G_{s}(s)=\frac{s^{2}+\alpha_{1} s}{s^{2}+\alpha_{1} s+\frac{K_{t}}{K_{t n}} \alpha_{2}}
$$

ここで, 外乱オブザーバの 2 次フィルタの遮断周 波数を制御系の動作周波数領域以上に十分大きくする と $P \rightarrow 0\left(\left|G_{s}(s)\right| \rightarrow 0\right)$ とでき, 図 11 のモ一夕側は外乱 の影響を受けないロバストな系となる.さらに, モ一 夕の参照指令值を式(15) とし, 微分プロセスを避け 高域のノイズを低減するために式 (16) に示す二次遅 れ要素 $G_{d}(s)$ を挿入すれば, システムが持つねじれ 反力の機械的フィードバックを打ち消すことができる. ただし， $K_{T p}, K_{T v}$ はトルク制御器での比例ゲインと 速度ゲインである.この二次遅れ要素の遮断周波数を 所望の動作周波数よりも大きく, すなわち, 所望の動 作周波数範囲で $G_{d}(s)=1$ とできれば理想的なトルク 制御系を表す式(17)が得られる.

$$
\begin{aligned}
\ddot{\theta}_{m}^{r e f} & =\left[\left(\frac{\ddot{T}_{a}^{d}}{K_{n}}+\ddot{\theta}_{a}\right) N+K_{T v}\left\{\left(\frac{\dot{T}_{a}^{d}}{K_{n}}+\dot{\theta}_{a}\right) N-\dot{\theta}_{m}\right\}\right. \\
& \left.+K_{T_{p}}\left\{\left(\frac{T_{a}^{d}}{K_{n}}+\theta_{a}\right) N-\theta_{m}\right\}\right] G_{d} \\
G_{d}(s) & =\frac{\beta_{2}}{\mathrm{~s}^{2}+\beta_{1} s+\beta_{2}} \\
J_{a} \ddot{\theta}_{a} & =\frac{K}{K_{n}} T_{a}^{d}-T_{e}
\end{aligned}
$$

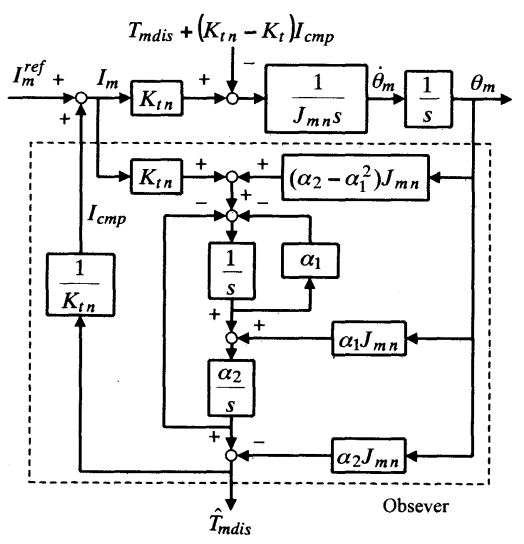

Fig.10 Observer-based joint system

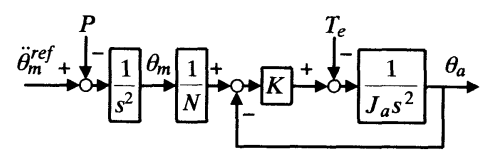

Fig.11 Equivalent block diagram of control system 
4.3 アーム回転角コントローラ 式(17)のダイ ナミクスで示されるアームに対して， $K_{\theta p}, K_{\theta v}$ を回 転角制御器での比例ゲインと速度ゲインとして, PD 制御による回転角コントローラを設計する.しかし， 単に式(17)を用いただけではアームが力を受けなが ら回転角制御する場合に大きな定常位置偏差を生じる. そこで, 式(12)から算出されるトルクを用いてトル クフィードバック ${ }^{(17)} し$, アームに加わる外乱を補償 する. ただし，起動時に発生する慣性トルクなどを過 補償しないために高周波数成分の影響を除く必要があ り,トルクフィードバック上に, 式(16) と同様の 2 次フィルタ $G_{T}(s)$ (係数は $\left.\gamma_{1}, \gamma_{2}\right)$ を㨉入する.

\section{4 制御モード切り替え法の適用 図 9 の解析} モデルに 4.2 節と 4.3 節の制御器, および位置と力の 偏差に基づく制御モード切り替え法を適用した制御系 全体のブロック線図を図 12 に示す。なお, 図 12 の破 線部は, 図8の制御モード選択器を示す.

\section{5. シミュレーション}

提案する制御モード切り替え法の有効性を検証する ため, また 6 章の実機実験で用いる制御パラメー夕を 決定するために図 9 のモデルについて MATLABを用い てシミュレーションを行った。計算に用いたパラメー 夕を表 1 に示す. 減速機付 DC サーボモータのパラ メー夕は, 市販されている定格出力 $18.5 \mathrm{~W}$ の DCサー ボモータのカタログから引用した. ただし, クーロン 摩摖係数 $T_{f}$, 粘性係数 $D_{m}$ は推測值である. また, 接 触する対象物はゴムとし, その剛性は志村らの 1 自由 度ロボットの実験結果(7を平面剛性に換算し $K_{e}=30000 \mathrm{~N} / \mathrm{m}$ とし, 対象物の粘性係数は不明なため $D_{e}=1 \mathrm{Ns} / \mathrm{m}$ とした. 制御には, モータ側とアーム側 の回転角センサ出力だけを利用した.アームはその先 端の球体部を対象物に接触するものと考え, アームに 作用する摩擦力等の非線形項と対象物之の衝突力は無 視し, 接触力は対象物の変形に要する值とした. さら に, モータと減速機の慣性モーメント, モータのトル クリプルおよびトルクセンサの㓮性変動はないものと 考光, $J_{m}=J_{m n}, K_{t}=K_{t n}, K=K_{n}$ とした.
5.1 トルク制御とアーム回轱角制御 アームを 対象物に接触させた状態を想定しトルク制御シミュ レーションを行なった. 速応性とオーバーシュートを 考慮し, 比例ゲイン $K_{T p}$ と速度ゲイン $K_{T v}$ を表 1 のよ うに決めた. 次に, アームを自由応答させ, 回転角制 御の位置ゲイン $K_{\theta p}$ と速度ゲイン $K_{\theta v}$ を, 速応性と 安定性の両面を考虑し表 1 のように決めた，ところで, アームに加わる外乱トルクを補償するためトルク フィードバックを施し 2 次フィルタ $G_{T}(s)$ を挿入し ているが, トルクフィードバックを強く(フィルタの 遮断周波数を高く)すればする程, 自由応答時にアー ム慣性により発生する外乱トルクを過補償する恐れが ある. そこで, 速応性と安定性の観点から, このフィ ル夕の係数 $\gamma_{1}$ と $\gamma_{2}$ を表 1 のように決定 ${ }^{(12)}$ した.

5.2 アーム回転角とトルクの制御提案する制 御モ一ド切り替え法を用いて, アーム初期位置から対 象物までの距離 $\theta_{0}$ を変化させた場合の 2 段階ステッ プ応答を図 13 に示す. ここで, 選択信号 $\Delta S$ が正で あればトルク制御を，0 または負であれば回転角制御 になっていることを意味する。なお，選択信号 $\Delta S$ は $\pm 1 \mathrm{Nm}$ に制限して示した. また, 前もってロボット

Table 1 System Parameters for simulation

\begin{tabular}{l|l|l|l|l}
\hline \hline DC Servo & Inertia & $J_{m}, J_{m n}$ & 0.0000081 & $\mathrm{Kgm}{ }^{2}$ \\
Motor with & Torque Constant & $K_{t}, K_{t n}$ & 0.0576 & $\mathrm{Nm} / \mathrm{A}$ \\
Reduction & Damping & $D_{m}$ & 0.005 & $\mathrm{Nm} \cdot \mathrm{s} / \mathrm{rad}$ \\
Gears & Friction & $T_{f}$ & 0.02 & $\mathrm{Nm}$ \\
& Gear Ratio & $N$ & 100 & - \\
\hline Elastic Body & Stiffness & $K, K_{n}$ & 100 & $\mathrm{Nm} / \mathrm{rad}$ \\
\hline Robot Arm & Inertia & $J_{a}$ & 0.0046 & $\mathrm{Kgm}$ \\
& Length of Arm & $L$ & 0.1 & $\mathrm{~m}$ \\
\hline Torque & Prop. FB Gain & $K_{T p}$ & 1000 & $1 / \mathrm{s}^{2}$ \\
Controller & Velocity FB Gain & $K_{T v}$ & 200 & $1 / \mathrm{s}$ \\
& Filter of Observer & $\alpha_{1}$ & 1950 & $\mathrm{rad} / \mathrm{s}$ \\
& & $\alpha_{2}$ & 950000 & $\mathrm{rad} / \mathrm{s}^{2}$ \\
& Filter $G_{d}$ & $\beta_{1}$ & 1950 & $\mathrm{rad} / \mathrm{s}$ \\
& & $\beta_{2}$ & 950000 & $\mathrm{rad} / \mathrm{s}^{2}$ \\
\hline Position & Prop. FB Gain & $K_{\theta p}$ & 100 & $\mathrm{Nm} / \mathrm{rad}$ \\
Controller & Velocity FB Gain & $K_{\theta v}$ & 10 & $\mathrm{Nm} \cdot \mathrm{s} / \mathrm{rad}$ \\
& Filter $G_{T}$ & $\gamma_{1}$ & 93 & $\mathrm{rad} / \mathrm{s}$ \\
& & $\gamma_{2}$ & 2170 & $\mathrm{rad} / \mathrm{s}^{2}$ \\
\hline Object & Stiffness & $K_{e}$ & 30000 & $\mathrm{~N} / \mathrm{m}$ \\
& Damping & $D_{e}$ & 1 & $\mathrm{Ns} / \mathrm{m}$ \\
\hline
\end{tabular}

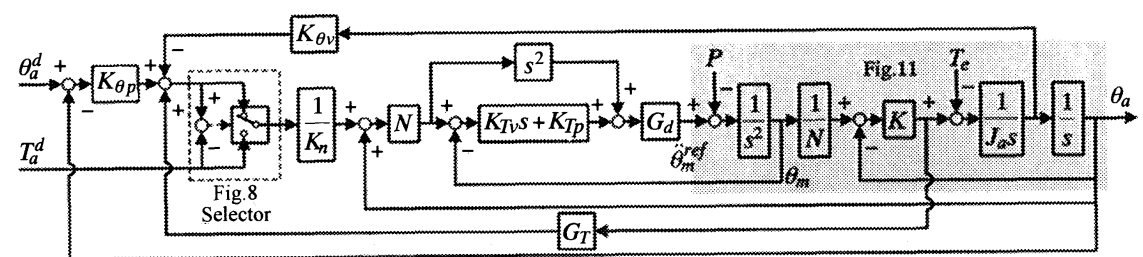

Fig.12 Block diagram of the total control system with the proposed method for switching control modes 
に対象物の位置情報を与えている訳ではなく，ロボッ トにとって対象物の位置は未知である. 図 13 より, 1 段目の $\theta_{a}^{d}=0.02 \mathrm{rad}$ の応答は全て回転角制御になっ ているが, 2 段目の $\theta_{a}^{d}=0.05 \mathrm{rad}$ の応答では, $\theta_{0}=0.04 \mathrm{rad}$ だとトルクを受けながらの回転角制御で あり, $\theta_{0}=0.03 \mathrm{rad}$ 以下だとトルク制御に切り替わっ ていることがわかる. また, 回転角制御では整定する までに 0.5 秒程度の遅れがあるが, 大きな振動は見ら れず回転角制御とトルク制御の制御モードが安定して 切り替わっていることが確認できる.

さらに, 図 14 に, トルク目標值を $4 \mathrm{Nm}$ とした上 で，まずアーム角度を $0.1 \mathrm{rad}$ に定回転角制御し，そ の後, 対象物を振幅 $0.1 \mathrm{rad}, 0.2 \mathrm{~Hz}$ の正弦波状の運 動でアームに繰り返し接触させた結果を示す.なお, 図中の細い実線は制御モードの間值 $T_{S}=2 \mathrm{Nm}$ とした 従来の切り替え法を用いた場合であり, この場合に限 り選択信号 $\Delta S$ に代わる信号として $T_{a}-T_{S}$ を示した. 従来の切り替え法(細い実線)では, 一旦トルク制御に

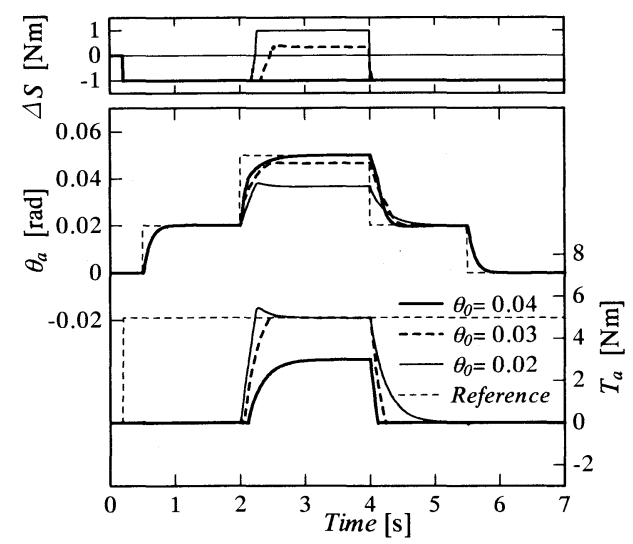

Fig.13 Simulation results of step response

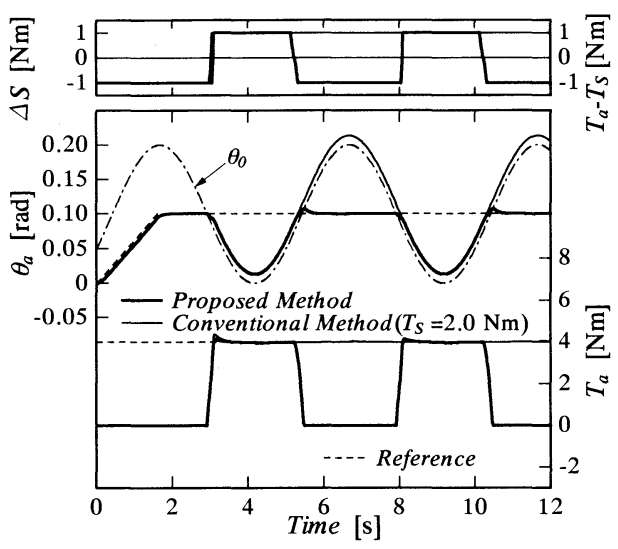

Fig.14 Simulation results of the object moving
切り替われば，対象物が回転角目標值から離れる場合 もトルク制御を保持しようと接触したまま対象物に追 随する。しかし，提案する制御モ一ド切り替え法(太 い実線) では, 選択信号 $\Delta S$ が振動なく正から負に変 化していることから，トルク制御から回転角制御にス ムーズに切り替わっていることが確認できる.

\section{6. 実}

弾性関節を有する 1 自由度ロボットを用いて実機実 験を行い, 提案する制御モード切り替え法の有効性を 検証する. 実験装置を図 15 に, 実験装置のパラメー夕 を表 2 に示す．駆動部にはハーモニックドライブギア式 の減速機付 DCサーボモータを使用し，アームの対極に カウンタウエイトを取り付けアームの重力項の影響を 小さくした，弾性体には $\phi 5.2 \mathrm{~mm}$, 長さ $50 \mathrm{~mm}$ の鉄製 丸棒を用いた。制御にはモー夕側とアーム側のエン コーダ出力のみを利用し, 弾性体に取付けたトルクセ ンサは弾性体の剛性 $K$ を求めるための予備実験とトル クのモニタのためだけに用いた. また, 対象物に接触 するアーム先端部分にステンレスの球体部 (袋ナット) を取付け, 実験には厚み $20 \mathrm{~mm}$ のゴム板を対象物とし て用いた.なお, 対象物への接触実験に先立ち, 弾性 体の剛性を実験的に求め $K=97.6 \mathrm{Nm} / \mathrm{rad}$ を得た.

図 16 に, アームと対象物までの距離を約 $20 \mathrm{~mm}$ と し, トルク目標值を $4 \mathrm{Nm}$ とした上で, アームを振幅 $0.262 \mathrm{rad}, 0.2 \mathrm{~Hz}$ の正弦波状の運動でゴム板に接触さ せた場合の実験結果を示す.なお, 制御のサンプリン グ時間は $2 \mathrm{~ms}$ とした. 従来の切り替え法では, 一旦 トルク制御に切り替われば，何らかの外的な判断機能 を用いて強制的に制御モードを切り替えなければ回転

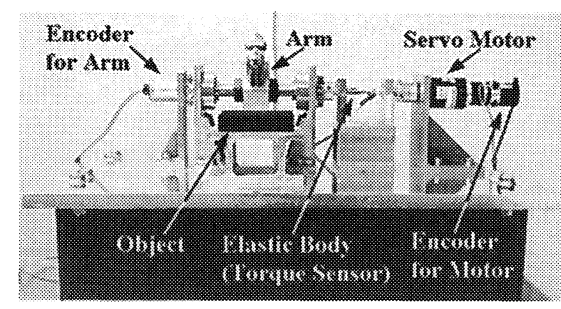

Fig.15 Experimental setup

Table 2 System parameters for experiment

\begin{tabular}{l|l|l|l}
\hline \hline DC Servo & Rated Output & 18.5 & $\mathrm{~W}$ \\
Motor with & Rated Torque & 5.9 & $\mathrm{Nm}$ \\
Reduction & Torque Constant & 5.76 & $\mathrm{Nm} / \mathrm{A}$ \\
Gears & Gear Ratio & 100 & - \\
& Rotary Encoder & 1000 & pulses/rev \\
\hline Robot Arm & Length of Arm & 0.10 & $\mathrm{~m}$ \\
& Rotary Encoder & 81000 & pulses/rev \\
\hline
\end{tabular}


角制御に切り替わることはないが，提案する手法では， 回転角目標値の変化に追随しトルク制御から回転角制 御にフレキシブルに制御モードが切り替わっているこ とが確認できる.

\section{7. 結}

ロボットの位置制御と力制御の制御モード切り替え 法について検討し, 以下の結果を得た.

（1）位置制御系と力制御系と制御モードを切り替え る選択器を有する位置と力の制御系を 2 種類に分類し, 制御モ一ドの切り替え時に位置制御と力制御の操作信 号が連続する制御系があることを示した。 なお，制御 モードの切り替え時に操作信号が連続し，かつ，それ ぞれの制御系が安定であるとすれば，制御モードを切 り替えても制御系の安定性には影響しないと判断でき る.

（2）位置と力の偏差から計算される位置操作信号と 力操作信号のうち, 小さい方の操作信号の制御モード を選択する，すなわち，先に目標值に達した方の制御 モードを選択する位置と力の偏差に基づく制御モード 切り替え法 (SCOME 法)を提案した.

（３）提案する制御モード切り替え法はシンプルなア ルゴリズムで実現できることを示し，弾性関節を有す る 1 自由度ロボットに対する回転角とトルクの切り替 え制御系を設計した。

（4）弾性関節を有する 1 自由度ロボットのシミュ レーションと実機実験により, 回転角制御からトルク 制御に, トルク制御から回転角制御にとフレキシブル に制御モードが切り替えられることを示し，提案する 制御モード切り替え法の有効性を示した.

\section{謝辞}

本研究は, 文部科学省学術フロンティア推進事業 「医工学研究の新展開」の支援を受けた.ここに記し て謝意を表する。また，本研究の一部は，（財）南海 育英会の支援を受けた，関係各位に謝意を表する.

\section{考文献}

(1) Kosuge, K., Force Control of Manipulators, Journal of the Robotics Society of Japan, Vol.9, No.6 (1991), pp.751-758.

(2) Kobayashi, H., et al., Actual robot control (in Japanese), (1997), pp.118-130, The Society of Instrument and Control Engineers.

(3) Hogan, N., Impedance Control, Part I -III, Transaction of the ASME, Journal of DSCM, No.107 (1985), pp.1-24.

(4) Yokoi, K., Maekawa, H., Tanie, K., A Method of Compliance Control for a Robotic Arm with Redundant Degrees of Freedom, Transactions of the Robotics Society of Japan, Vol.11, No.1 (1993), pp.121-130.

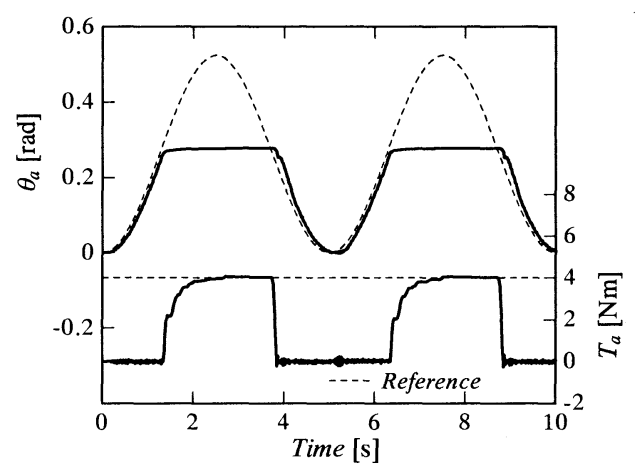

Fig.16 Experimental results

(5) Hyde, J.M. and Cutkosky, M.R., Contact Transition Control: An Experimental Study, Proceedings of the IEEE International Conference on Robotics and Automation, (1993), pp.363-368.

(6) Yangming, X., Hollerbach, J.M. and Donghai, M., Force and Contact Transient Control Using Nonlinear PD Control, Proceedings of the IEEE International Conference on Robotics and Automation, (1994), pp.924-930.

(7) Shimura, K., and Hori, Y., Robustified Force and Collision Control for Robot Manipulator, Transactions of the Robotics Society of Japan, Vol.11, No.2 (1993), pp.235-245.

(8) Raibelt, M.H., and Craig, J.J., Hybrid Position/Force Control of Manipulators, Transactions of the ASME, Journal of Dynamic Systems, Measurement and Control, Vol.102, (1981), pp.126133.

(9) Shimada, A., et al., Next Generation's Motion Control and The practical use of it (in Japanese), Technical report of the Institute of Electrical Engineers of Japan, No.734 (1999), pp.56-59.

(10) Yamada, T., and Yabuta, T., Changing Method of Control Mode for Manipulators at Impact of Objects, Proceedings of the 20th ISIR, (1989), pp.593-600.

(11) Itabashi, K., Yamada, K., Suzuki, T., Okuma, S., Contact Force Control Based on Learning Operation without Switching the Servo Mode at the Instant of the Impact, Transactions of the Japan Society Mechanical Engineers, Series C, Vol. 62, No.596 (1996), pp.1473-1479.

(12) Yamasaki, Y., Yokogawa, R., Hara, K., A Changing Method of Position and Force Control Modes for an Articulated Manipulator Coming in Contact with Soft Objects, The Science and Engineering Review of Doshisha University, Vol.39, No.1 (1998), pp.21-32.

(13) Suhara, M., Miyagi, J., Yamasaki, Y., “A Feedback Controller of Hydraulic Pump", Japanese Patent No.2011322.

(14) Kayukawa, H., Yamada, H., Muto, T., Fundamental Study of Power-Match Control of Hydraulic Power Systems (PowerMatch Control Applied to a Physical Model of Injection Molding Machine), Transactions of the Japan Society Mechanical Engineers, Series C, Vol. 61, No.588 (1995), pp.3295-3302.

(15) Kaneko, K., Suzuki, N., Ohnishi, K., Tanie, K., A Study on the Torque Control of a DC Motor With Reduction Gears (2nd, Report), Transactions of the Japan Society Mechanical Engineers, Series C, Vol. 58, No.546 (1992), pp.484-491.

(16) Ohnishi, K., Robust Motion Control by Disturbance Observer, Journal of the Robotics Society of Japan, Vol.11, No.4 (1993), pp.486-493.

(17) Hashimoto, M., Motion Control of Robot Arms with Reducers Based on Joint Torque Feedback, Transactions of the Society of Instrument and Control Engineer, Vol.25, No.2 (1989), pp.188-193. 